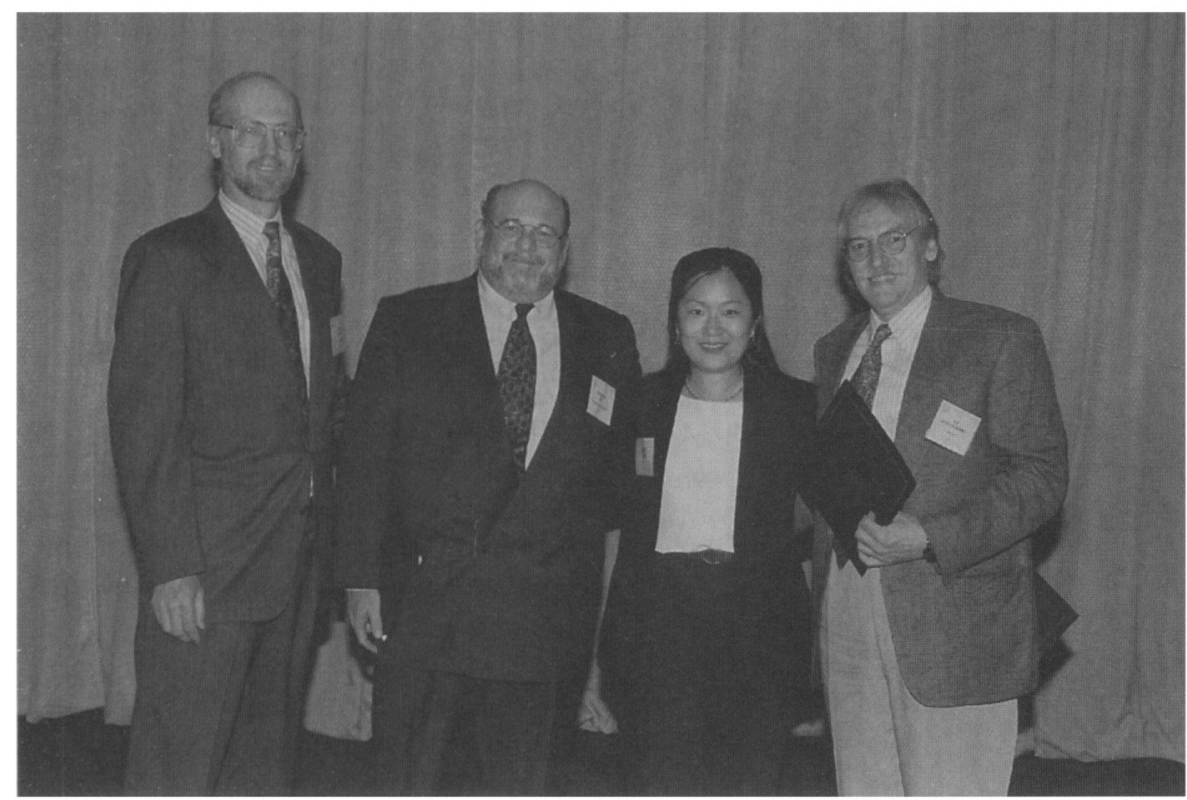

John McIver, University of Colorado (L), chair of the 1997 Woodrow Wilson Foundation Award Committee, with recipients ( $L$ to $R$ ) Norman Nie, University of Chicago, Jane Junn, Rutgers University, and Kenneth Stehlik-Berry, SPSS, Inc. The trio won were recognized for their book Education and Democratic Citizenship in America (University of Chicago Press).

University). Amy Beth Zegart, California State University, Sacramento, won the Leonard D. White Award for the best dissertation in the field of public administration for "In Whose Interest? The Making of American National Security Agencies" (Chair: Stephen Krasner, Stanford University).

National awards were also given for outstanding conference papers and books. The Pi Sigma Alpha/ Franklin L. Burdette Award for the best paper presented at the 1996 Annual Meeting went to Richard Brisbin, West Virginia University, for "The U.S. Supreme Court and the Rationality of Labor Violence: The Impact of the Mackay Radio Doctrine and 'Violence' during the Coal Strike of 1989-90." James D. Fearon and David D. Laitin, both of the University of Chicago, shared the Heinz Eulau Award for the best paper published in the American Political Science Review during 1996 for "Explaining Interethnic Cooperation" (90[4]: 715-35). Amy Gutmann, Princeton University, and $\mathrm{K}$. Anthony Appiah, Harvard University, shared the Ralph J. Bunche Award for the best scholarly work in political science published in 1996 which explores the phenomenon of ethnic and cultural pluralism for Color Conscious: The Political Moral- in 1996 on women and politics went to Kristi Andersen, Syracuse University, for After Suffrage: Women in Partisan and Electoral Politics Before the New Deal (University of Chicago Press). Jane Junn, Rutgers University, Norman Nie, University of Chicago, and Kenneth Stehlik-Barry, SPSS Inc., shared the Woodrow Wilson Foundation Award for the best book published in 1996 on government, politics, or international affairs for Education and Democratic Citizenship in America (University of Chicago Press).

Full citations for all awards appear in "The Gazette" in this issue of PS. For information on 1998 APSA awards, or to make nominations, contact Sean Twombly at twombly@apsanet.org.

\section{Annual Meeting Short Courses Draw Large Crowds}

As part of the Annual Meeting's "Professional Day" programs, eleven short courses were offered in Washington the day before this year's Annual Meeting. Sponsored by a range of organizations, including several APSA Organized Sections, the Institute for Contemporary Studies, and the Northeast Association of PreLaw Advisors, the 1997 courses provided opportunities for political sci-

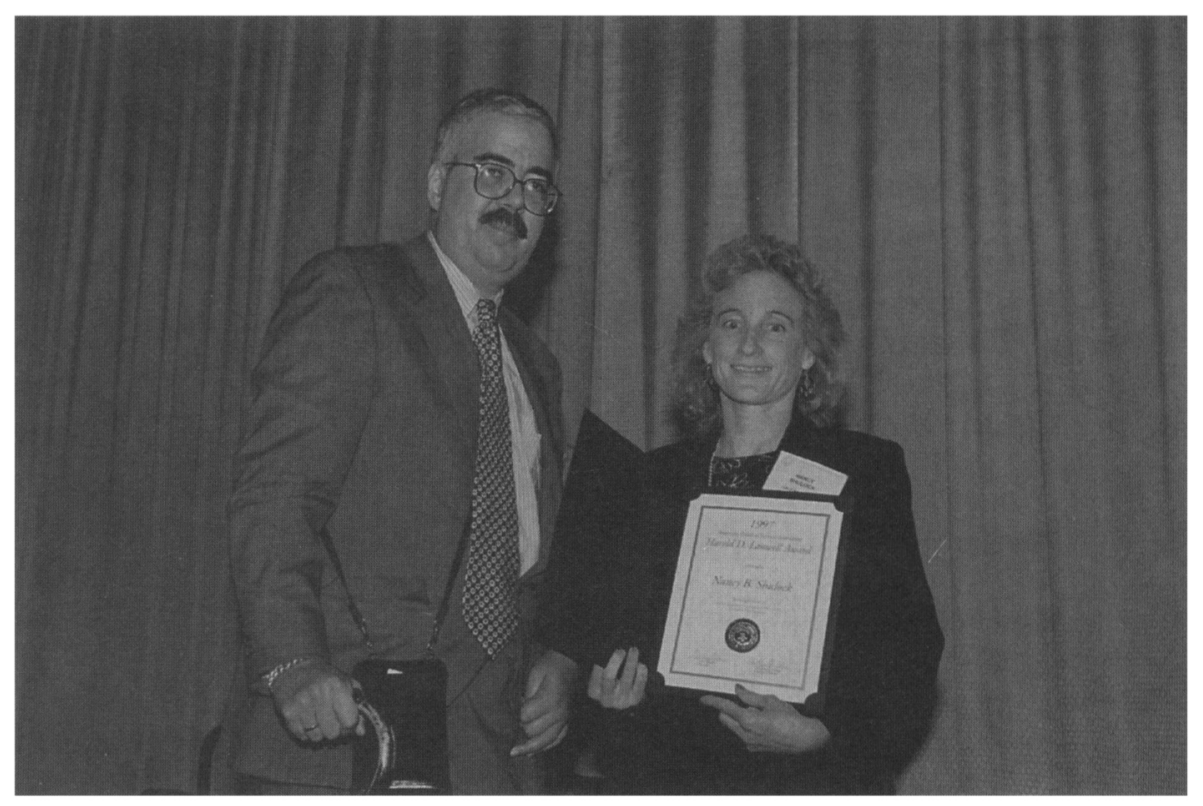

William Diaz, Hubert Humphrey Institute, University of Minnesota, chair of the 1997 Harold D. Lacsswell Award Committee, presents the prize to Nancy B. Shulock, California State University, Sacramento. Shulock's dissertation is titled "Interpretive Theory of Policy Analysis." 


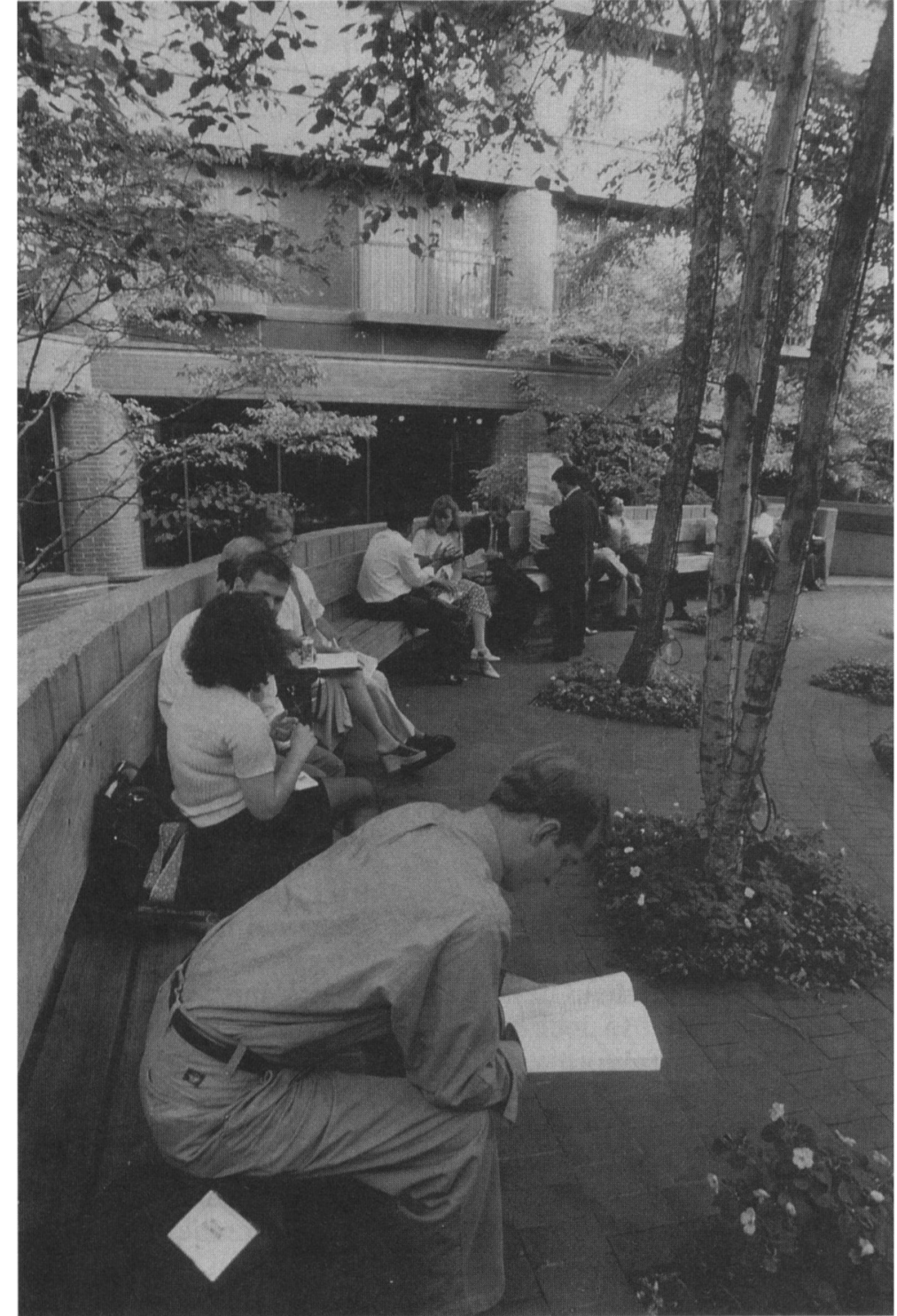

1997 Annual Meeting attendees pause for a moment before returning to one of the 650 panel sessions organized by the Program Committee chaired by James Alt, Harvard University, and Margaret Len, University of Washington.

entists and graduate students to learn new teaching and research skills, understand trends in U.S. policymaking, and listen to senior scholars reflect on the profession. Nearly 200 Annual Meeting attendees participated in this year's short course program.

The 1997 selection included the Eighth annual Leading Scholars Series, this year featuring former APSA President Arend Lijphart, University of California, San Diego and current APSA Vice President G. Bingham Powell, University of Rochester. The session, attended by over 30 graduate students, served as an extraordinary opportunity for graduate students to meet two highprofile political scientists and gain from their insight into the profession.

Over sixty scholars joined Gary King of Harvard University as he led a course entitled "A Method for Ecological Inference." The full-day course presented a practical, applied introduction to the methods presented in his recent book, $A$ Solution to the Ecological Inference Problem: Reconstructing Individual Behavior From Aggregate Data (Princeton University Press, 1997), including how to use the method to make valid inferences about individual behavior from aggregate data.
The Program also featured a course on "Using the Records of Congress," which introduced nearly thirty scholars to the resources available at the Center for Legislative Archives, where the historical records of the U.S. Congress are housed by the National Archives and Records Administrations. Conducted by the staff at the Center, the course covered several topics of interest to researchers and teachers and included briefings by Senate Historian Richard Baker and Director of the House Legislative Resource Center John Kornacki.

The Organized Section on International Security and Arms Control sponsored "Strategic Weapons Proliferation and Superterrorism," drawing attention to two of the most significant emerging threats to U.S. national security. Nearly three dozen scholars attended the course and heard commentary by such notables as former Director of Central Intelligence James Woolsey, former CIA Deputy Director (Intelligence) Douglas MacEachin, now at Harvard University, and Peter Feaver, Duke University. Henry Sokolski of The Nonproliferation Policy Education Center led the course.

Among the other courses offered were "Fair Division: From CakeCutting to Dispute Resolution," led by Stephen Brams; "How Not to Reinforce the Political Cynicism of Undergraduates When Teaching American Politics," convened by the Institute for Contemporary Studies; "Pre-Law Advising and the Political Scientist"; "Political Myth, Rhetoric, and Symbolism"; "Implementing Devolution: Federal, State, and Local Perspectives"; "Religion and the Democracy in the Middle East and Latin America: Comparing Christian Democracy with Islamic Democracy"; and "Models of Political Choices."

Plans for the 1998 Short Course Program are presently being made. Those interested in sponsoring short courses at the 1998 meeting in Boston should contact APSA Deputy Director Rob Hauck at rhauck@apsanet.org. 